https://doi.org/10.15407/scin16.01.069

PASHCHENKO, E.O., KUKHARENKO, S.A., RIABCHENKO, S.V, BYCHKYHIN, V.M., and SHATOKHIN, V.V.

V. Bakul Institute for Superhard Materials, the NAS of Ukraine, 2, Avtozavodska St., Kyiv, 04074, Ukraine,

+38044430 7694, lab6_1@ukr.net

\title{
DEVELOPMENT OF THE TECHNOLOGY FOR MANUFACTURING AND INTRODUCING A NEW CLASS OF TOOLS WITH CVD DIAMOND FOR GRINDING HIGH-PRECISION GEAR WHEELS OF SPECIAL REDUCER UNITS
}

Introduction. The trueing tool used by machine-building enterprises of Ukraine creates a fundamental constraint for improving the accuracy of shaping of the working profile of abrasive wheels and, accordingly, the accuracy of the products made with its use.

Problem Statement. The creation of CVD diamonds tools is in the process of being finalized by leading foreign developers. This class of CVD diamond trueing tool has never been developed or manufactured in Ukraine.

Purpose. The development of a technology for manufacturing precision products from CVD diamond for providing the process of grinding the gear wheels of special reducer units at mechanical engineering enterprises.

Materials and Methods. Techniques and special stands for precise positioning of elements from CVD diamond and for testing the trueing instrument, methods for determination of metallic binder's structure.

Results. The rational positioning of CVD diamond elements on the cases of complex shapes has been studied. The manufactured tools for trueing abrasive wheel have been finished and tested. It has been shown that the use of such elements provides a high resistance to the erosion influence of sludge in the trueing area and is expedient to be used in contact with the main components of abrasive wheels, due to exceptional tribological characteristics. The use of structured metallic binders has been shown to provide low vibrations in the trueing area and a stable and reproducible topography of the cutting surface of an abrasive tool with a large number of cutting edges and with the capability of directional influence on the orientation of the edges by selecting efficient trueing conditions.

Conclusions. For the first time in Ukraine, at the Bakul Institute for Superhard Materials of the NAS of Ukraine, the truing tools equipped with CVD diamond elements have been created and adapted to the processing chains of high-precision gear wheels of reducer units with enhanced operational characteristics, which enable replacing the imported parts at the machine-building enterprises of Ukraine.

Keywords: CVD diamond, structured metallic binders, and superhard materials.

Citation: Pashchenko, E.O., Kukharenko, S.A., Riabchenko, S.V, Bychykhin, V.M., and Shatokhin, V.V. Development of the Technology for Manufacturing and Introducing a New Class of Tools with CVD Diamond for Grinding High-Precision Gear Wheels of Special Reducer Units. Sci. innoz. 2020. V. 16, no. 1. P. 69-75. https://doi.org/10.15407/scine16.01.069 
The enhancing requirements for the quality of manufactoring machines are related to the need to improve their accuracy and reliability, productivity and efficiency, which largely depend on the performance parameters of their major components and units. Mechanical engineering needs fundamentally new, reliable, and versatile equipment, tools and accessories capable of effectively and steadily machining various products made of structural materials under conditions of both large-scale computer-aided manufacture and small factories that are widespread today. This concerns gears wheels that are an integral part of the structural units of most modern machines. This requires a significant increase in the intensity of the gears operation (up to $140 \mathrm{~m} / \mathrm{s}$ in circular velocity, up to $7000 \mathrm{~N} / \mathrm{cm}$ specific loads, and up to $300{ }^{\circ} \mathrm{C}$ the operating temperature), combined with the need to reduce weight and to increase resource of their service. The performance parameters of reducer units depend primarily on the quality of the gear wheels. The manufacture of gear wheels of the required precision is a multi-stage process, the results of which are largely determined by the state of the cutting profile of the grinding wheel used for gear machining. Maintaining the geometry and cutting ability of the abrasive profile of product is the purpose of trueing operation. There are many types and variety of trueing instrument that can be classified according to different characteristics. The important thing is the nature of the trueing tool surface that contacts the grinding composite, the object of trueing. Such a surface may be discrete or continuous. In the first case, we are dealing with the tools equipped with powders of natural or synthetic diamond, in the second one, this means the solid rotation bodies made of high hardness and wear resistant materials.

The disadvantage of the trueing tools with the continuous support surface is a close topography of the abrasive wheel surface, which is formed as a result of trueing. This significantly increases the cutting force and contact temperature arising while grinding the gear wheel and, accordingly, impairs the structural condition and geometry of the workpiece at an economically acceptable stock removal rate. On the other hand, in this case, the vibration amplitude in the contact area of the trueing tool with the abrasive wheel is stable, which positively affects the reproducibility of the wheel profile shape after each trueing, provided the trueing composite is highly stable. The trueing tools based on high-strength diamond powders form an open topography of the abrasive surface, giving it a high cutting power. However, even in the case of programmable distribution of grains on the surface of the tool body, which is an extremely labor-consuming operation, it is impossible to avoid formation of long tracks free of diamond particles, on the cutting layer. This causes cyclically recurring fluctuations of the cutting force. When such cyclical fluctuations resonate with the self-induced vibrations of the trueing tool and the abrasive product, i.e. the object of trueing, the aggregate vibrations in the work area get significantly intensified, which leads to a quick wear of the trueing tool, deterioration of the micro-geometry of the abrasive wheel cutting surface and the profile accuracy. Thus, the stochastic nature of the orientation of the cutting edges of diamond powder grains, even the highstrength isometric fractions, creates considerable constraints for further improving the accuracy of shaping of the abrasive wheel working profile and, ultimately, affects the accuracy of the products obtained using the trued abrasive tool.

An obvious approach to the solution of the above described dilemma is the creation of trueing tools with a combined surface that connects the work of high-strength diamond grains with arbitrarily oriented cutting edges and the effect of regularly spaced sections of a certain length with continuous topography of contact with the abrasive wheel. However, as numerous publications and experience have shown [1-3], this apparent formulation of the problem does not guarantee the expected scientific and technical solution. Thus, today the use of elements made of boron carbide, silicon carbide, or polycrystalline 

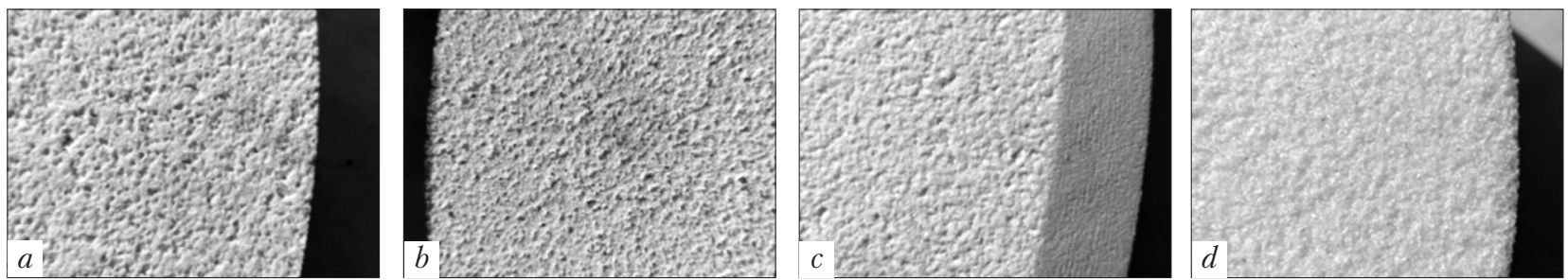

Fig. 1. Examples of the structures of grinding wheels of white electrocorundum with grain size F60, by the numbers of structure: $a-12 ; b-11 ; c-9 ; d-6$

diamond has not enabled solving the problem of stable trueing of grinding wheels for machining gear wheels of high-precision reducer units.

According to recent publications, as well as our previous research [4-8], the probable solution of the problem is to create trueing tools with a combined work surface using CVD-diamond elements (inserts). This solution is promising, given an extremely high resistance of the tools to the erosion impact of grinding dust in the trueing area and its exceptional tribological characteristics in contact with the main components of abrasive wheels. It is just this property that provides a stable mode of vibration during the trueing process, i.e. the reproducibility and stability of the parameters of the abrasive tool cutting profile, on the one hand, and the geometry and structure of the workpiece, on the other hand. The binder plays an important role in ensuring a stable mode of contact interaction between the trueing tool and the abrasive wheel. In the conventional binder, the removal is made with a small amount of the most prominent grains. The elementary cell of the grain contacting with the machined material has a considerable area and an extremely high energy density. This gives rise to the uneven nature of the impact of the tool on the profile of the abrasive wheel. At V. Bakul Institute for Superhard Materials of the NAS of Ukraine, there have been developed fundamentally new approaches to creating structured metal binders suitable for the creation of tools with a combination of high-strength diamond grains and long elements with high hardness and wear resistance. Structured-bonded diamond grains form an even-altitude ensemble in the cutting area. A large number of grains are in- volved in the stock removal. There are numerous elemental cells of grains contact with the machined material, they have a small volume and differ insignificantly in «degree of overheating». This ensures a low level of vibration in the trueing area and, accordingly, a stable and reproducible topography of the cutting surface of the abrasive tool with a large number of cutting edges and with the possibility of targeted influence on their orientation by selecting proper trueing modes. The tool operation on structured binder creates a spectrum of native vibrations of abrasive grains in the form of one or multiple narrow frequency bands, that is, provides coherent grinding.

The tools for precision shaping of abrasive wheels form the most complex, in terms of manufacture, the most attractive, from the economic point of view, and the most critically important, in terms of application, segment of instrumentmaking industry. The technological problem is that the above mentioned new class of CVD-diamond trueing tool has never been developed or manufactured in Ukraine. However, it has been widely used at machine-building enterprises of Ukraine for trueing of modern abrasive wheels while grinding the gear wheels of special reducer and other products. Nowadays, the creation of tools with the use of CVD-diamond and their manufacturing technology are being refined by leading foreign developers. Given this, the solution of this scientific and technical problem for the needs of domestic engineering is a relevant and urgent task.

The purpose of this research is to develop a manufacturing technology and implementation of a new class of CVD-diamond trueing tool for 


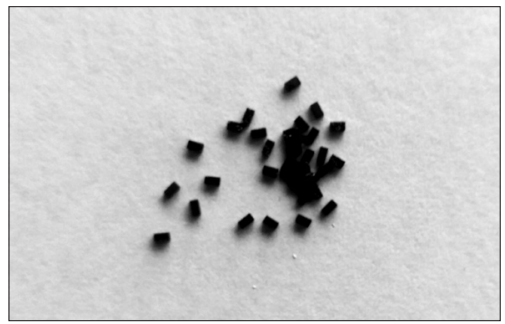

Fig. 2. CVD-diamond crystals

abrasive grinding of gear wheels of special reducers, based on the accumulated experience of the V. Bakul Institute for Superhard Materials of the NAS of Ukraine in manufacturing diamond trueing tools for the needs of machine-building enterprises of Ukraine and solving the problem of import substitution of such tool.

The solving a number of issues is necessary to achieve this purpose. Firstly, the development of technology for the production of a new class of CVD-diamond trueing tools, is required, as well as methods and special test stands to study the operability of CVD-diamond trueing tool. Secondly, it is important to know the relationship between the initial characteristics of the abrasive wheels, the characteristics of the trueing tool and the conditions of trueing, on the one hand, and the wear pattern of the diamond tool, the stability period and the initial parameters of gear wheels grinding process, on the other hand. Thirdly, it is necessary to develop recommendations for the optimal parameters of the formation of abrasive wheels with specified characteristics for the gear grinding process.

The main materials for the production of gear wheels are carbon and alloy steels. The most responsible gear wheels are made of special hardmachined alloys, for which low carbon alloy steels are preferably used having undergone chemical thermal treatment, cementation, and hardened up to HRC 50 and higher. The cylindrical gear wheels of the 3 rd -7 th degree of precision are conventionally divided into the three groups, depending on their precision: the precise (7th degree), the high-precision (5th-6th degree), and the extra high-precision (3rd-4th degree). The precise and high-precision gear wheels are widely used in engineering industry and machine-tool building, while the extra high-precision ones are used in turbo-, aircraft- and machine-tool building (the manufacture of precision machines), as well as in other industries.

Highly porous abrasive wheels have significant advantages over the tools of normal porosity while machining the parts made of high-alloy steels and alloys in the cases when the limiting factors are high requirements for the absence of "burns" and cracks in the process of grinding. For example, such parts are turbine blades, gears wheels, worm cutters, running screws and so on. The highly porous grinding wheels have a high self-sharpening ability, are manufacturable in terms of profiling and trueing, and enable grinding of parts with less heat release in the cutting area, as compared with the conventional wheels [1]. The wheel structure is indicated by numbers and does not differ significantly from different manufacturers. It is divided into 12 groups. The higher the number, the lesser the abrasive grains in tool volume, the more binder and pores at the same hardness. For example, for structure 1, the volume content of abrasive grains in the tool is $62 \%$, for the next structure number the grain volume decreases by $2 \%$. The European standard ISO / FDIS 6103 establishes the structure numbers for abrasive tools from 0 to 14, i.e. 15 groups. Examples of the structure of grinding wheels made of white electrocorundum are shown in Fig. 1.

In the production of abrasive wheels for grinding gears are used mainly different types of electrocorundum (aluminum oxide) and cubic boron nitride. These abrasive materials are made the dish wheels for Maag, the cup wheels for Gleason machines, the conical wheels for Niles machines, the worm wheels for Reishauer machines and profile grinding wheels.

Thick-layer CVD-diamond (Fig. 2) shall be considered as material that is an alternative to natural and polycrystalline diamonds. It has the same extremely high chemical and physical parameters as natural diamonds as well as synthetic 


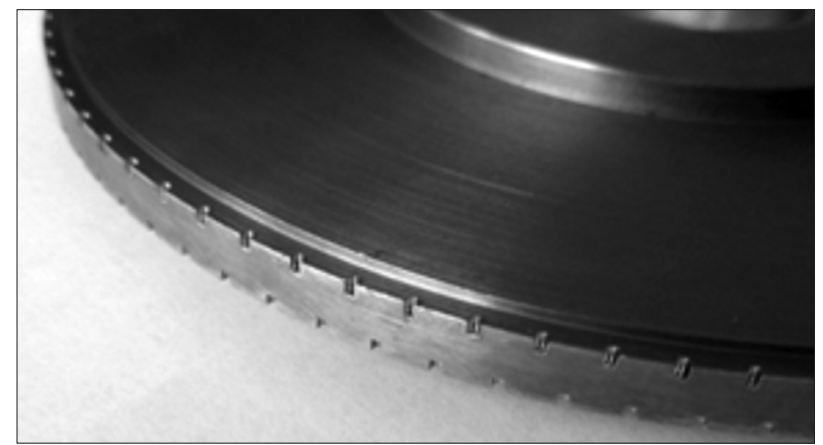

Fig. 3. The roller housing with milled grooves

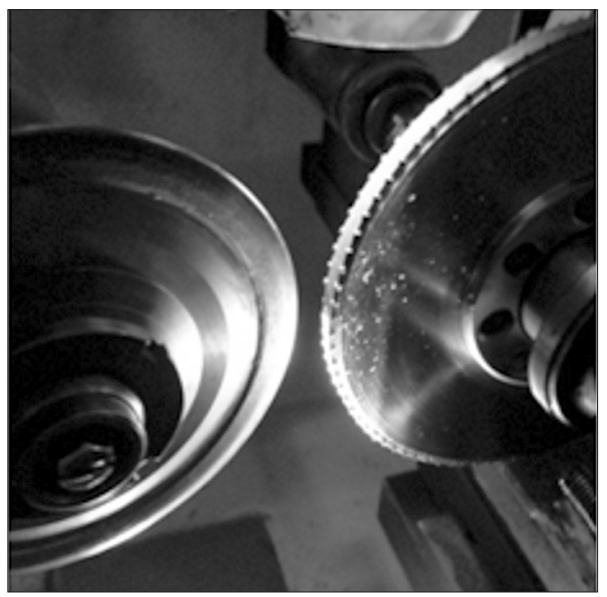

Fig. 4. Finishing of the roller on the optogrinding machine

diamonds produced at high pressure and temperature. In fact, it is pure carbon that does not contain a binder phase. However, since CVD-diamond consists of fused diamond microcrystals, it is a polycrystalline substance. As in the case of many materials grown by using the thin-film technology, the CVD-diamond crystals are formed from small crystallization seeds that are coalescing during the enhancement and thickening of the layer making it stem-structured. The CVDdiamonds are chemically inert, have a high thermal conductivity and resistance to abrasive wear. The possibility to use CVD-diamonds for the manufacture of diamond rollers and other abrasive trueing tools is of particular interest. It means, there is a unique possibility of manufacturing products that have exactly the same working ele-

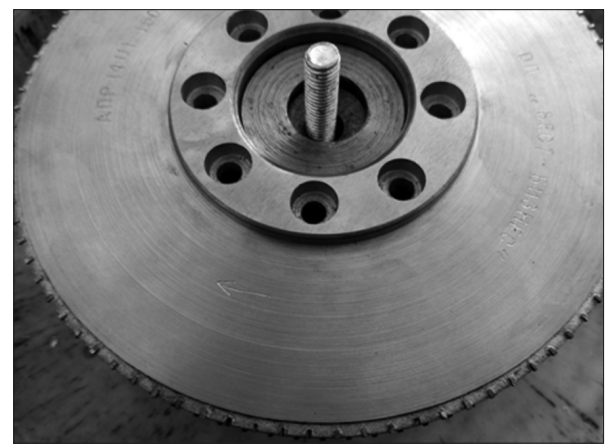

Fig. 5. Trueing CVD-diamond roller

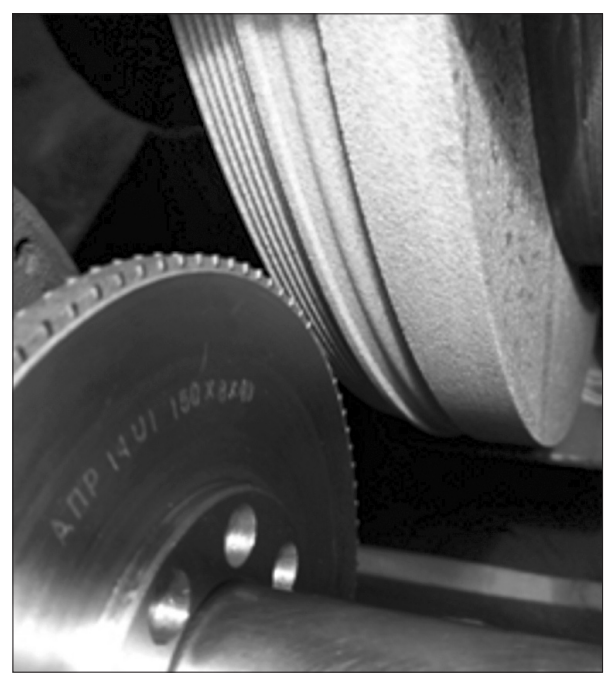

Fig. 6. Trueing CVD-diamond roller when dressing the grinding wheel

ments and, consequently, the same (optimum) contact area with the working surface of the abrasive wheel, which, as known, is of fundamental importance both for the quality of trueing and for the general service life of the trueing element.

The CVD-diamond trueing roller was performed using an AutoCAD computer program that meets all the standard requirements for designing a special diamond tool and the customer's specifications for such dressing rollers. When designing the trueing roller, all safety requirements for manufacturing the dressing rollers and the equipment for making the diamond tool on adhesive active metal binder were taken into account. The roller housing material is steel 45 that, when app- 
lying the diamond-bearing metal layer in vacuum, does not lead to a significant distortion of the tool body. Similarly, when designing the trueing roller configuration, designers took into account the existing equipment fleet for machining and finishing the diamond rollers, which could ensure the accuracy production of the CVD-diamond roller. Machining CVD-diamond trueing rollers combines turning the tool body, milling grooves for mounting diamond crystals, finishing tool bores, drilling tool bore for screws and engraving the tool's characteristics on the body. Finishing CVD-diamond trueing rollers includes finishing grinding of the working layer along the end and the periphery of the roller, measuring the accuracy indicators of the roller, and final finishing of CVDdiamond crystals on an opto-grinding machine. The trueing roller housing is turned on numerically programmable control (NCP) screw-cutting lathe of mark 2P22. The treatment is made with one stop of the roller workpiece on the lathe to avoid any loss of base surfaces at further processing. The roller is machined in the diameter, cut of the roller ends, machined the flange, and turned the tool bores. Such the operations approach to turning allowed the provision of the required precision of the roller housing for its further manufacture. The next machining operation of trueing roller is milling grooves for mounting CVDdiamond crystals on the body. This operation is made on a three-coordinate milling machine with NPC. Totally, 180 grooves (90 on each side) having a size of $1.0 \times 1.2 \mathrm{~mm}$ are milled over every 4 degrees, on the periphery of the roller body. The roller workpiece with milled grooves is shown in Fig. 3. Finishing treatment of the tool bore to a size of $40.002 \mathrm{~mm}$ is made on grinding machine (model 3D366). The bores are drilled on a vertical drilling machine $2 \mathrm{M} 37$, using $\varnothing 5.5 \mathrm{~mm}$ drills, with subsequent countersinking of the bore on the $\varnothing 10 \mathrm{~mm}$ screw head. The characteristics of the tool are engraved last, after the completion of all operations, before packaging the roller.

A separate operation of trueing roller manufacture is the insertion of CVD-diamond crystals into the milled grooves of the roller housing. For this operation, a special fixture was made on model IZV-2 instrument microscope. The roller is placed on a special cylinder fixed in the center on the microscope table. The diamond crystals are fixed in the grooves of the roller housing with a special glue that burns out in a vacuum furnace, while applying the adhesive metal binder. The roller is finished on the optical-grinding machine OSHL-237 using a diamond grinding wheel on metal binder. The roller periphery and the two end faces are trued to the accuracy specified in working drawings. Fig. 4 shows the process of finishing the roller on optical-grinding machine. The final operations on the manufacture of the trueing roller consisted of the measurements its accuracy and engraving the characteristics on the roller body.

The CVD-diamond trueing roller (Fig. 5) has been tested at the enterprise PJSC Motor-Sich (Zaporizhia, Ukraine) while trueing high-porous abrasive wheels when grinding gears made of hardened steels on NPC machine tool Pfauter-KAPP (Germany). The trueing of a grinding wheel by a CVD-diamond roller is shown in Fig. 6.

The tests have shown that the use of CVD-diamond elements (inserts) is expedient due to its extremely high resistance to erosive effect of grinding dust in the trueing area and exceptional tribological characteristics while contacting the main components of abrasive wheels.

Thus, for the first time in Ukraine, the V. Bakul Institute of Superhard Materials for the NAS of Ukraine has created a finished scientific and technical product, trueing tool on structured metal binders, equipped with elements of CVDdiamond and adapted to technological chains of production of high-precision gear wheels for reducers with high performance characteristics, which enables import substitution at domestic enterprises, as well as entry into foreign markets, and, consequently, attraction of foreign currency to funding of the NAS of Ukraine. The CVD-diamond trueing rollers have been experimentally implemented at Motor Sich PJSC, which is confirmed by technical certificates. 


\section{REFERENCES}

1. Starkov, V. K. (2007). Grinding with highly porous circles. Moscow [in Russian].

2. Riabchenko, S. V., Sereda, G. V., Riabchenko, A. S. (2014). Grinding processes of materials with highly porous abrasive wheels. Industry in focus, 38, 58 [in Russian].

3. Riabchenko, S. V., Sereda, G. V. (2011). Abrasive wheels for grinding gear wheels. Equipment and tools for professionals, 4 (138), 54-56 [in Russian].

4. Ignatov, V., Pashchenko, E. (2011, May) The prospect of the formation of self-organizing surfaces of the workpieces by grinding with adaptive composites. Proceedings of an International Technical Conference on Diamond, Cubic boron nitride and their applications, Chicago.

5. Pashchenko, E. A., Kukharenko, S. A., Bychykhin, V. N., Lazhevskaya, O. V., Nekoval', N. N., Dovgan', A. G. (2015). New promising abrasive tool materials for the aviation industry. Instrumental World, 1-4 (61-64), 80-84 [in Russian].

6. Kumar, A., Kovalchenko, A., Pashchenko, E., Pogue, V. (2016). Ductile Mode Behavior of Silicon During Scribing by Spherical Abrasive Particles. Procedia CIRP, 45, 147-150.

7. Pashchenko, E. A., Lazhevskaya, O. V., Chernenko, A. N., Savchenko, D. A., Nekoval', N. N. (2016). Investigation of the efficiency of abrasive composites forming active technological media in the cutting zone. Rock-destroying and metalworking tools - technique and technology of its production and application, 19, 421-427 [in Russian].

8. Riabchenko, C. V. (2018). Grinding of gear wheels in circles of superhard materials. Cutting and Tools in Technological Systems, 89 (101), 158-164 [in Russian].

Received 01.04.19

Revised 04.04.19

Accepted 24.06.19

Є.О. Пашенко, С.А. Кухаренко,

С.В. Рябченко, В.М. Бичихін, В.В. Шатохін

Інститут надтвердих матеріалів ім. В.М. Бакуля НАН України,

вул. Автозаводська, 2, Київ, 04074, Україна,

+380 44430 7694, lab6_1@ukr.net

РОЗРОБКА ТЕХНОЛОГІЇ ВИГОТОВЛЕННЯ ТА ВПРОВАДЖЕННЯ

НОВОГО КЛАСУ ІНСТРУМЕНТУ З CVD-АЛМАЗУ ДЛЯ ШЛІФУВАННЯ

ВИСОКОТОЧНИХ ЗУБЧАСТИХ КОЛІС СПЕЦІАЛЬНИХ РЕДУКТОРІВ

Вступ. Правлячий інструмент, який використовують на машинобудівних підприємствах України, створює принципові обмеження для подальшого підвищення точності формоутворення робочого профілю абразивних кругів і, відповідно, впливає на точність виробів, виготовлених з його використанням.

Проблематика. Створення інструментів з використанням CVD-алмазу перебуває на стадії доопрацювання у провідних зарубіжних розробників. Цей клас правлячого інструменту з CVD-алмазу ніколи не розроблявся та не виготовлявся в Україні.

Мета. Розробка технології виготовлення прецизійних виробів з CVD-алмазу для інструментального забезпечення процесу шліфування зубчастих коліс спеціальних редукторів на підприємствах машинобудування.

Матеріали й методи. Методики та спеціальні стенди для точного позиціонування елементів з CVD-алмазу та для випробування правлячого інструменту, методи визначення структури металічних зв’язок.

Результати. Досліджено раціональне позиціонування елементів з CVD-алмазу на корпусах складних форм. Проведено фінішну доводку та випробування виготовлених інструментів в процесах правки абразивних кругів і показано, що використання таких елементів забезпечує високу стійкість до ерозійного впливу шламу в зоні правки та $€$ доцільним з виключними трибологічними характеристиками в контакті з основними складовими абразивних кругів. Показано, що використання структурованих металічних зв'язок забезпечує низький рівень вібрацій в зоні правки й стабільну і відтворювану топографію ріжучої поверхні абразивного інструменту з великою кількістю ріжучих кромок та з можливістю спрямованого впливу на орієнтацію останніх шляхом вибору раціональних режимів правки.

Висновки. Вперше в Україні, в Інституті надтвердих матеріалів ім. В.М. Бакуля НАН України, створено правлячі інструменти, оснащені елементами з CVD-алмазу, та адаптовано їх до технологічних ланцюгів виготовлення високоточних зубчастих коліс для редукторів з підвищеними експлуатаційними характеристиками, що дає можливість імпортозаміщення на машинобудівних підприємствах України.

Ключові слова: CVD-алмаз, структуровані металічні зв'язки, інструмент з надтвердих матеріалів. 